\title{
Revised Technical Action Plan at Former Commodity Credit Corporation Grain Storage Sites in Nebraska and Kansas
}

Applied Geoscience and Environmental Management Section,

Environmental Research Division,

Argonne National Laboratory, 9700 South Cass Avenue, Argonne, Illinois 60439

\section{DISCLAIMER}

\begin{abstract}
This report was prepared as an account of work sponsored by an agency of the United States Government. Neither the United States Government nor any agency thereof, nor any of their employees, makes any warranty, express or implied, or assumes any legal liability or responsibility for the accuracy, completeness, or usefulness of any information, apparatus, product, or process disclosed, or represents that its use would not infringe privately owned rights. Reference herein to any specific commercial product, process, or service by trade name, trademark, manufacturer, or otherwise does not necessarily constitute or imply its endorsement, recommendation, or favoring by the United States Government or any agency thereof. The views and opinions of authors expressed herein do not necessarily state or reflect those of the United States Government or any agency thereof.
\end{abstract}

January 1993

Work sponsored by Commodity Credit Corporation, United States Department of Agriculture 


\section{Contents}

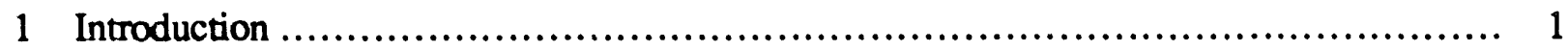

1.1 Background.............................................................. 1

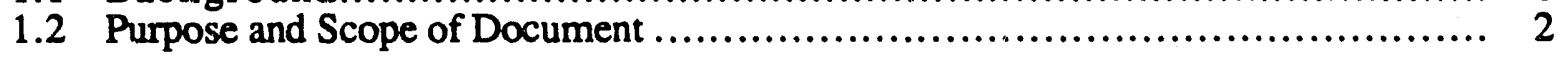

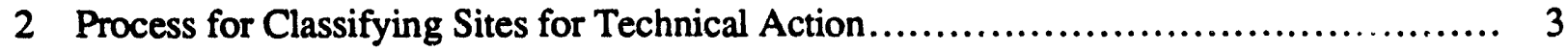

3 Summary of Sites and Proposed Technical Actions................................. 5

3.1 Summary of Sites............................................................. 5

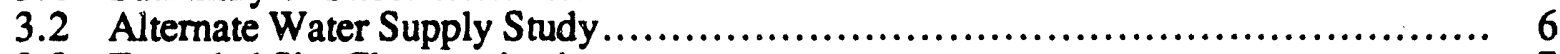

3.3 Extended Site Characterization .................................................... 7

\section{Tables}

1 Technical Action Proposed for USDA/CCC Sites in Nebraska and Kansas

\section{Figures}

1 Process for Classifying USDA/CCC Sites for Technical Action.

2 Alternate Water Supply Study: Proposed Scheduling for USDAVCC Kansas and Nebraska Sites.

3 Extended Site Characterization: Proposed Scheduling for USDA/CCC Kansas and Nebraska.

4 Alternate Water Supply Study: Approach for Screening and Analysis of Alternatives

5 Alternate Water Supply Study: Representative Task Profile for Single USDA/CCC Site.

6 Extended Site Characterization: Representative Task Profile for USDA/CCC Site. 


\section{Revised Technical Action Plan at Former Commodity Credit Corporation Grain Storage Sites in Nebraska and Kansas}

\section{Introduction}

This document has been prepared for the Commodity Credit Corporation of the U.S. Department of Agriculture (USDA/CCC) to provide an outline for a multiyear plan for technical investigations at sites in Kansas and Nebraska that have been identified as having groundwater contamination. Carbon tetrachloride is the primary contaminant of concern at sites in Nebraska and Kansas where former USDA/CCC grain storage facilities were located.

\subsection{Background}

Over the past few years, the USDA/CCC has been actively involved in site characterization and groundwater cleanup activities, under the Comprehensive Environmental Response, Compensation, and Liability Act (CERCLA), at sites in Murdock and Waverly, Nebraska. Since 1991, the U.S. Environmental Protection Agency (EPA) Region VII (Kansas City, Kansas), with input from the state public health departments and environmental control agencies, has identified to the USDA/CCC 75 additional locations in Kansas and Nebraska where various levels of carbon tetrachloride contamination have been reported in the groundwater.

The USDA/CCC, along with EPA and the state agencies, recognizes the need to address the reported groundwater contamination problems in a timely manner. Doing so will protect public drinking water supplies and public heaith as well as the environment. To address these groundwater contamination problems, the USDA/CCC has committed and continues to commit resources and funding to investigate the contaminated sites further. The USDA/CCC has asked Argonne National Laboratory, Environmental Research Division, for assistance in developing a technical plan for site classification and investigation. 


\subsection{Purpose and Scope of Document}

This document outlines a multiyear, multisite plan for technical actions to be taken by the USDA/CCC at specific sites in Nebraska and Kansas. The Revised Technical Action Plan demonstrates the continuing commitment of the USDA/CCC to respond to reported carbon tetrachloride contamination problems at former USDA/CCC grain storage facilities.

Presented in this document are (1) a list of the EPA-identified sites in Nebraska and Kansas and the technical actions proposed by the USDA/CCC and (2) proposed time lines for activities at each site. The technical actions proposed by the USDA/CCC include Alternate Water Supply Studies and Extended Site Characterization activities.

The Revised Technical Action Plan and time lines should be viewed as parts of a dynamic, flexible process, because the prioritization or order of site evaluation can be altered with changes in USDA/CCC, state, or EPA priorities. However, by establishing a set process of investigation, the USDA/CCC and Argonne can prioritize activities, plan, and allocate resources, the last including but not limited to funds, staff, expertise, and equipment. The Revised Plan will also provide the EPA and the states with a guide to current and upcoming USDA/CCC technical actions at USDA/CCC sites.

Only sites that were previously identified by the EPA and/or the state agencies as having carbon tetrachloride contamination in the groundwater are considered in this Revised Technical Action Plan. The original Technical Action Plan at Former Commodity Credit Corporation Grain Storage Sites in Nebraska and Kansas (prepared by Argonne National Laboratory for the USDA/CCC, January 1992) stated that the EPA and/or state agencies had identified 30 sites. An additional 45 sites have now been identified and are included in this Revised Plan. Because the plan is dynamic, sites can be added and deleted with changing priorities, as evidenced by this revision. In addition, the proposed time lines are tentative and subject to change with changing priorities of the USDA/CCC, the EPA, and/or the state. The timing of activities is also subject to budget approval for any given fiscal year.

This document is not intended to be a technical work plan and does not provide specific details about the technical investigations to be conducted at the sites. Technical project plans (work plans including health and safety, quality assurance, and community relations plans) will be prepared as required for the individual sites. 


\section{Process for Classifying Sites for Technical Action}

The technical actions proposed by the USDA/CCC and discussed in this document include the following:

- Alternate Water Supply Study (AWSS). The purpose of an AWSS is to identify options for providing an alternate drinking water supply to a community whose supply source is contaminated at a level that may be a potential threat to public health.

- Extended Site Characterization (ESC). ESC studies will be conducted at certain communities to identify, prioritize, and respond to sites about which additional information is required.

These two technical actions provide a streamlined approach to (1) quickly address the public health concerns at sites that are reported to have contaminated drinking water supplies and (2) address the subsequent (or concurrent) need for additional site characterization to fully determine the need for environmental remediation.

Sites were classified for action by using the maximum carbon tetrachloride concentrations reported for the water supply by the EPA and state public health departments. The classification process is shown in Figure 1 and described here.

Carbon Tetrachloride Concentration
Less than 4 parts per billion (ppb)
Greater than or equal to $4 \mathrm{ppb}$
Greater than or equal to $160 \mathrm{ppb}$

\begin{tabular}{l} 
Preliminary Response Action \\
\hline No action needed \\
AWSS conducted; ESC deferred \\
AWSS and ESC conducted
\end{tabular}

The value of $4 \mathrm{ppb}$ (parts per billion) for carbon tetrac.lloride in the water supply was chosen as the numeric trigger to indicate the need for an AWSS. The criterio: for selecting this trigger level is the Safe Drinking Water Act (SDWA) maximum concentration level (MCL) for carbon tetrachloride of $5 \mathrm{ppb}$. In addition, sites with reported carbon tetrachloride contamination levels of $4 \mathrm{ppb}$ were included as a quality assurance measure, to ensure compliance with the SDWA standard. The sites needing an AWSS were ranked by concentrations and/or a site-specific factor that upgraded the priority. For example, at a site where all the community supply wells are 
contaminated and/or an administrative order is in place or about to be issued, such as at Hordville, Nebraska, the priority would be upgraded because of the site-specific factor.

For sites with reported concentrations of $4-6 \mathrm{ppb}$, the first step of the AWSS will be to review the sampling data and verify the need for the study. Site-specific factors such as sampling frequency, data reproducibility, and frequency of contaminant detection will be considered. A site will be classified as "no action" or "no need for AWSS" if the data for that site do not support continued detection at levels over $5 \mathrm{ppb}$ or if the carbon tetrachloride contamination is related to no potential threat to public health.

The value of $160 \mathrm{ppb}$ is the 10-day health advisory level for carbon tetrachloride in drinking water. This concentration level was used to prioritize sites that will be scheduled for ESC activities. The 10-day health advisory level was selected on the basis of the information in the EPA's Guidance Document for Providing Alternate Water Supplies, Appendix D, "Interim Final Guidance on Removal Action Levels of Contaminated Drinking Water Sites" (1988).

The concentration level $160 \mathrm{ppb}$ was not used to rule out the need for or the intention to conduct further investigations at sites with concentrations below $160 \mathrm{ppb}$, but rather to identify sites that should be given the highest priority. Sites with concentrations of 4-160 ppb are now scheduled for an AWSS and in the future may require and receive additional site characterizations. However, in an effort to schedule and allocate resources, only sites with a concentration over $160 \mathrm{ppb}$ are scheduled for an ESC in this Revised Plan. The decision and planning for additional actions (beyond the AWSS) at sites with concentrations less than $160 \mathrm{ppb}$ are deferred at present.

As Figure 1 shows, the process includes a decision point, "USDA/CCC Accepts Preliminary Responsibility." This decision point allows the USDA/CCC to make a preliminary determination to initiate or not initiate an investigation or further action at a site. Issuance of this Revised Plan implies only that the USDA/CCC recognizes the problem and a need for resolution and that the USDA/CCC agrees to use its resources to investigate further. It does not imply the USDA/CCC's acceptance of responsibility or Potential Responsible Party (PRP) status. Any site that is currently scheduled in the Revised Plan has been preliminarily accepted. However, the acceptance status may change at any time in the process. As investigations proceed, the USDA/CCC may decide to decline any responsibility if the data indicate that the USDA/CCC is not responsible. It is assumed that the EPA will continue its efforts to identify other contributing or responsible parties and will require cleanup assistance from the other parties while the USDA/CCC-Argonne investigations are in progress. 


\section{Summary of Sites and Proposed Technical Actions}

\subsection{Summary of Sites}

Site names and the proposed preliminary technical actions are shown in Table 1 . In all, 75 sites have been identified by the EPA and/or state agencies as having carbon tetrachloride contamination in the groundwater. Of these sites, 34 have reported carbon tetrachloride contamination below the trigger level of $4 \mathrm{ppb}$; no further action is required at those sites. Another 7 sites have not been included in the current project scheduling for AWSS activities, but these sites could be added to the schedule at a later date The remaining 34 sites have been selected to receive an AWSS.

The sampling data from 8 of the 34 sites scheduled for AWSS activity (Cortland, Johnson, and Ruskin, Nebraska, and Agenda, Randall, Frankfort, Perry, and Powhatton, Kansas) will first be subjected to review and confirmation to determine if the contamination levels are high enough to require an AWSS. A projected time line for the proposed AWSS activities is shown in Figure 2. To date, AWSS reports have been submitted to the USDA/CCC for Hordville (April 1992), Utica (June 1992), and Shelby (September 1992), Nebraska, and for Navarre (June 1992) and Plainville (December 1992), Kansas.

Five sites (Navarre, Plainville, and Morrill, Kansas, and Utica and York, Nebraska) are scheduled for an ESC study in addition to the AWSS. These five sites were selected for immediate action because contamination levels exceeded the 10-day health advisory levels, as discussed in Section 2 . The ESC will be conducted concurrently with or slightly after the AWSS. Projected time lines for the ESC studies are shown in Figure 3. ESC activities have been :nitiated for three sites (Navarre, Kansas, and Utica and York, Nebraska).

Extended site characterization activities for the other 29 sites (Hordville, Shelby, Aurora, Bruno, Hubbard, Clay Center, Adams, Humphrey, Deshler, Cortland, Emerald, Gladstone, Martell, Tamora, Funk, Kenesaw, Ceresco, Johnson, and Ruskin, Nebraska, and Hacirney, Potwin, Agra, Leoti, Agenda, Randall, Ramona, Frankfort, Perry, and Powhatton, Kansas'; are deferred at this time. Deferred action does not necessarily imply that no site characterization will be conducted. As stated previously, this list should be viewed as dynamic. 
Seven sites (Hastings and Walton, Nebraska, and Yoder, Wright, Bendena, Hutchinson, and Washington Co. Rural Water District No. 1, Kansas) have not been scheduled to receive an AWSS. However, these sites could be scheduled for an AWSS at a later date.

\subsection{Alternate Water Supply Study}

An AWSS may be conducted when community (public or private) drinking water supplies are reported to be contaminated with carbon tetrachloride. The objective of the AWSS is to identify options for providing a safe drinking water supply to all users, in compliance with the requirements of the Safe Drinking Water Act.

The AWSS planned by the USDA/CCC will be conducted according to the procedures outlined in the EPA's Guidance Document for Providing Alternate Water Supplies, EPA/540/G87/006, February 1988. The study approach, summarized in Figure 4, will include (1) evaluation of the need for an alternate supply, (2) engineering and cost evaluations, and (3) implementation of the selected alternative. If the evaluation of the need for an alternate water supply confirms that an adequate supply of potable water is available to meet the needs of the community, then further AWSS activities are not warranted. Otherwise, the AWSS continues with engineering and cost analyses of alternate water supply options.

A representative time line for full-scale AWSS activities at one site is shown in Figure 5. An AWSS report will be prepared at the completion of each study to document the evaluation process and to provide a comparative analysis of the potential water supply alternatives. Selection of the remedy for implementation will be made by the USDA/CCC with input from the affected community, the EPA, and the state agency. The actual implementation (engineering design and construction) of the selected remedy will be contracted by the USDA/CCC to appropriately qualified engineering, geology, or water well drilling firms, with technical review by Argonne or other USDA/CCC contractors. The alternate supply to be implemented will, in all cases, be selected to provide a safe supply to the users; the alternative is not required to provide any remediation of the contaminated groundwater. In some cases, the selected alternative may be intended as an interim supply that can be altered or supplemented after the extended site characterization study is complete, as shown in the flow chart in Figure 1. 


\subsection{Extended Site Characterization}

Extended site characterization investigations will determine the distribution of contamination within an aquifer, the general characteristics of the aquifer system, and whether a remedial action is necessary or feasible (Figure 1). The sites selected for extended site characterization in Nebraska and Kansas and the proposed schedule for implementing these investigations are given in Figure 3.

A representative task profile illustrating the timing proposed for various activities in the site characterization program is given in Figure 6. These time lines are approximate and may vary with the complexity and size of a site. In general, Phase I field activities will concentrate on surface geophysical activities such as the use of seismic and electrical methods for subsurface geology and aquifer mapping, the sampling of existing wells, measuring the water level for calculations of the direction of flow, soil borings, and subsurface sampling with tools such as the cone penetrometer or HydroPunch. Phase II activities will incorporate any additional sampling and monitoring well installation required to define the aquifer system. Both Phase I and Phase II field programs may require two-event staging to maximize the efficiency of data collection. 
Table 1 Technical Action Proposed for USDA/CCC Sites in Nebraska and Kansas

\begin{tabular}{|c|c|c|c|c|c|}
\hline Site & $\begin{array}{c}\text { Carbon } \\
\text { Tetrachloride } \\
\text { Concentration } \\
\text { (ppb) }\end{array}$ & $\begin{array}{l}\text { Type of } \\
\text { Water } \\
\text { Supply }\end{array}$ & $\begin{array}{l}\text { Proposed } \\
\text { Action(s) }\end{array}$ & $\begin{array}{l}\text { AWSS } \\
\text { Completed } \\
\text { on Date }\end{array}$ & $\begin{array}{c}\text { ESC } \\
\text { Activities } \\
\text { Initiated } \\
\text { on Date }\end{array}$ \\
\hline
\end{tabular}

Carbon tetrachloride concentration $\geq 160$ ppb

(Alternate Water Supply Study and Extended Site Characterization conducted)

$\begin{array}{llllcc}\text { Navarre, KS } & 552 & \text { Private } & \text { AWSS and ESC } & 6 / 92 & 4 / 92 \\ \text { Utica, NE } & 170 & \text { Public } & \text { AWSS and ESC } & 6 / 92 & 6 / 92 \\ \text { York, NE } & 440 & \text { Private } & \text { AWSS and ESC } & - & 9 / 92 \\ \text { Plainville, KS } & 320 & \text { Public } & \text { AWSS and ESC } & 12 / 92 & - \\ \text { Morrill, KS } & 184 & \text { Public } & \text { AWSS and ESC } & - & -\end{array}$

Carbon tetrachloride concentration $\geq 4$ ppb and $<160$ ppb

(Alternate Water Supply Study conducted; Extended Site Characterization deferred)

\begin{tabular}{|c|c|c|c|c|c|}
\hline Hordville, NE & 37 & Public & AWSS & $4 / 92$ & - \\
\hline Shelby, NE & 23 & Public & AWSS & $9 / 92$ & - \\
\hline Hackney, KS & 155 & Private & AWSS & - & - \\
\hline Aurora, NE & 84 & Public & AWSS & - & - \\
\hline Potwin, KS & 61 & Public & AWSS & - & - \\
\hline Bruno, NE & 37 & Public & AWSS & - & - \\
\hline Hubbard, NE & 22 & Public & AWSS & - & - \\
\hline Clay Center, NE & 15 & Public & AWSS & - & - \\
\hline Adams, NE & 12 & Public & AWSS & - & - \\
\hline Humphrey, NE & 12 & Public & AWSS & $\cdot$ & - \\
\hline Agra, KS & 12 & Public & AWSS & $\cdot$ & - \\
\hline Leoti, KS & 12 & Public & AWSS & - & - \\
\hline Deshler, NE & 7 & Public & AWSS & - & - \\
\hline Cortland, NE & 6 & Public & AWSS & - & - \\
\hline Agenda, KS & 6 & Public & AWSS & - & - \\
\hline Randall, KS & 6 & Public & AWSS & - & - \\
\hline Emerald, NE & 65 & Public & AWSS & $\cdot$ & - \\
\hline Gladstone, NE & 55 & Private & AWSS & - & - \\
\hline Ramona, KS & 45 & Private & AWSS & - & - \\
\hline Martell, NE & 36 & Public & AWSS & - & - \\
\hline Frankfort, KS & 4 & Public & AWSS & - & - \\
\hline Perry, KS & 4 & Public & AWSS & $\cdot$ & - \\
\hline Powhatton, KS & 4 & Public & AWSS & - & - \\
\hline Tamora, NE & 21 & Private & AWSS & - & - \\
\hline Funk, NE & 10 & Public & AWSS & - & - \\
\hline Kenesaw, NE & 10 & Public & AWSS & - & - \\
\hline Ceresco, NE & 9 & Public & AWSS & - & - \\
\hline Johnson, NE & 6 & Public & AWSS & - & - \\
\hline Ruskin, NE & 6 & Public & AWSS & - & - \\
\hline
\end{tabular}


Table 1 (Cont.)

\begin{tabular}{cccccc}
\hline & Carbon & & & ESC \\
Tetrachloride & Type of \\
Concentration & Water \\
Site & Supp) & Proposed & Action(s) & $\begin{array}{c}\text { AWSS } \\
\text { Completed } \\
\text { on Date }\end{array}$ & $\begin{array}{c}\text { Activities } \\
\text { Initiated } \\
\text { on Date }\end{array}$ \\
\hline
\end{tabular}

Possible Additional Sites

(Alternate Water Supply Study and Extended Site Characterization currently not scheduled)

Yoder, KS
Hastings, NE
Walton, NE
Wright, KS
Bendena, KS
Hutchinson, KS
Washington Co.
Rural Water
District No. 1,
KS

Carbon tetrachloride concentration < 4 ppb (no action needed)

\begin{tabular}{|c|c|c|c|}
\hline Rising City, NE. & 3.3 & Public & None \\
\hline McPherson, KS & 2.7 & Public & None \\
\hline Barnes, KS & 2.5 & Public & None \\
\hline Valentine, NE & 2.5 & Public & None \\
\hline Glasco, KS & 2.4 & Public & None \\
\hline Woodbine, KS & 2.4 & Private & None \\
\hline Ness City, KS & 2.2 & Public & None \\
\hline Morrowville, KS & 1.8 & Public & None \\
\hline Bloomfield, NE & 1.7 & Public & None \\
\hline St. Mary's, KS & 1.5 & Public & None \\
\hline Minneapolis, KS & 1.2 & Public & None \\
\hline Laurel, NE & 1.2 & Public & None \\
\hline Salina, KS & 1.1 & Public & None \\
\hline Arapahoo, NE & 1.0 & Public & None \\
\hline Marquette, NE & 1.0 & Public & None \\
\hline Stromsburg, NE & 1.0 & Public & None \\
\hline Concordia, KS & 1.0 & Public & None \\
\hline Haddam, KS & 1.0 & Public & None \\
\hline Moundridge, KS & 1.0 & Public & None \\
\hline Browstnr, KS & 1.0 & Public & Nono \\
\hline Sharon, KS & 1.0 & Public & None \\
\hline Country Side, KS & 0.9 & Public & None \\
\hline White City, KS & 0.8 & Public & None \\
\hline Bruning, NE & 0.8 & Public & None \\
\hline
\end{tabular}


Table 1 (Cont.)

\begin{tabular}{lccccc}
\hline \multicolumn{1}{c}{ Site } & $\begin{array}{c}\text { Carbon } \\
\text { Tetrachloride } \\
\text { Concentration } \\
\text { (ppb) }\end{array}$ & $\begin{array}{c}\text { Type of } \\
\text { Water } \\
\text { Supply }\end{array}$ & $\begin{array}{c}\text { Proposed } \\
\text { Action(s) }\end{array}$ & $\begin{array}{c}\text { AWSS } \\
\text { Completed } \\
\text { on Date }\end{array}$ & $\begin{array}{c}\text { Activities } \\
\text { Initiated } \\
\text { on Date }\end{array}$ \\
\hline & Carbon tetrachloride concentration <4 ppb (no action ne日ded) (Cont.) & \\
Edgar, NE & 0.5 & Public & None & - & - \\
Geneva, NE & 0.5 & Public & None & - & - \\
Mason City, NE & 0.5 & Public & None & - & - \\
Bradshaw, NE & 0.5 & Public & None & - & - \\
Coleridge, NE & 0.3 & Public & None & - & - \\
Loomis, NE & 0.3 & Public & None & - & - \\
Newman Grove, NE & 0.3 & Public & None & - & - \\
Ellis, KS & 0.2 & Public & None & - & - \\
Springfield, NE & 0.2 & Public & None & - & - \\
Sterling, NE & 0.2 & Public & None & - & - \\
\hline
\end{tabular}


Figure 1 Process for Classifying USDA:CCC Sites For Technical Action

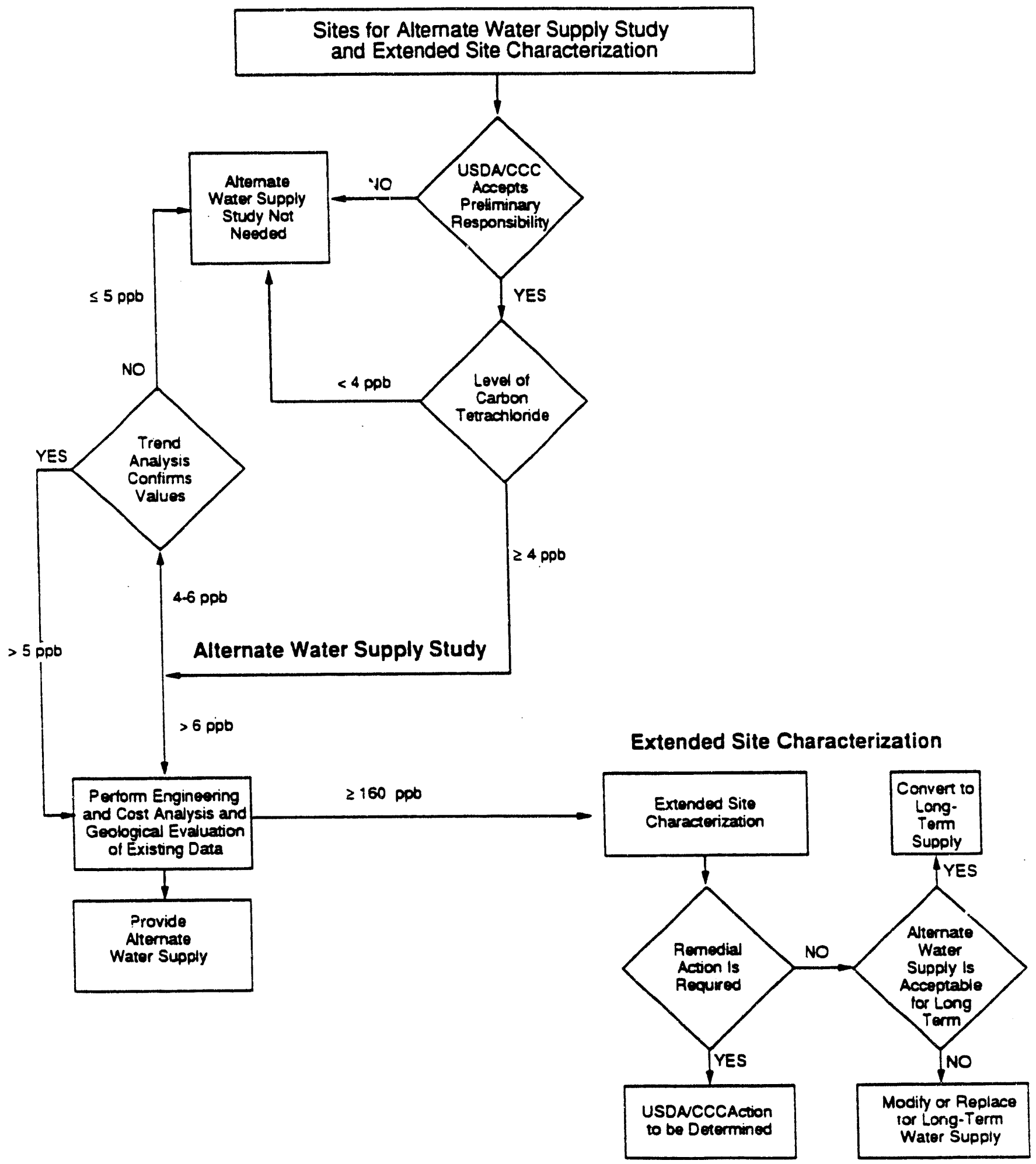




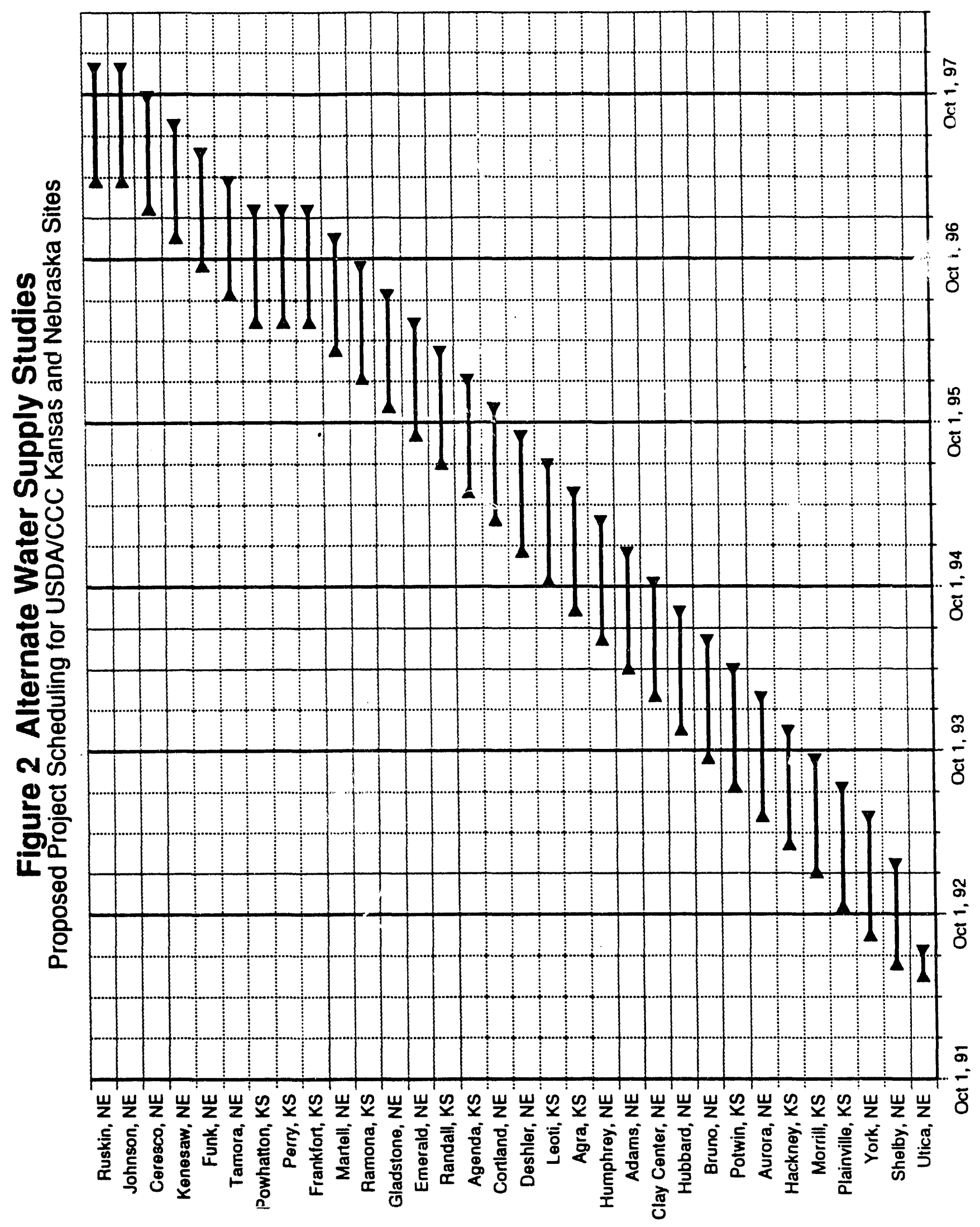




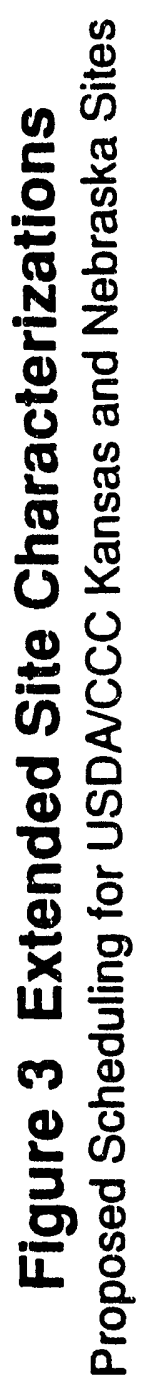

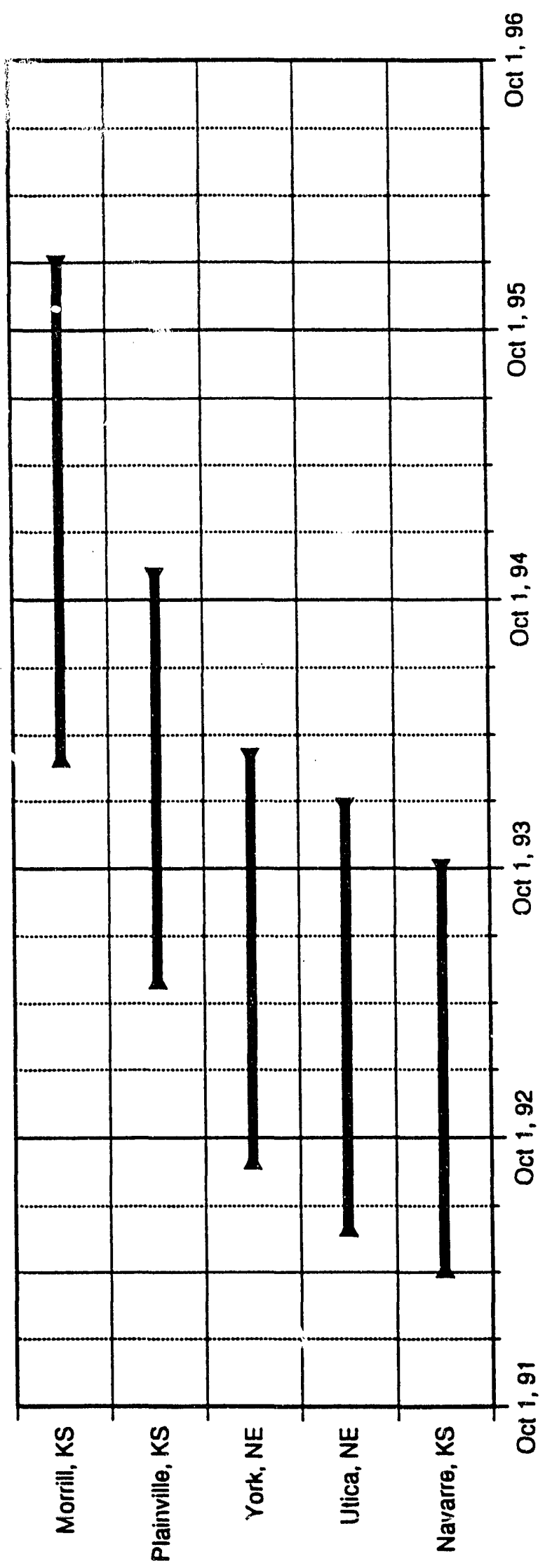


Figure 4 Alternate Water Supply Study Approach for Screening and Analysis of Alternatives

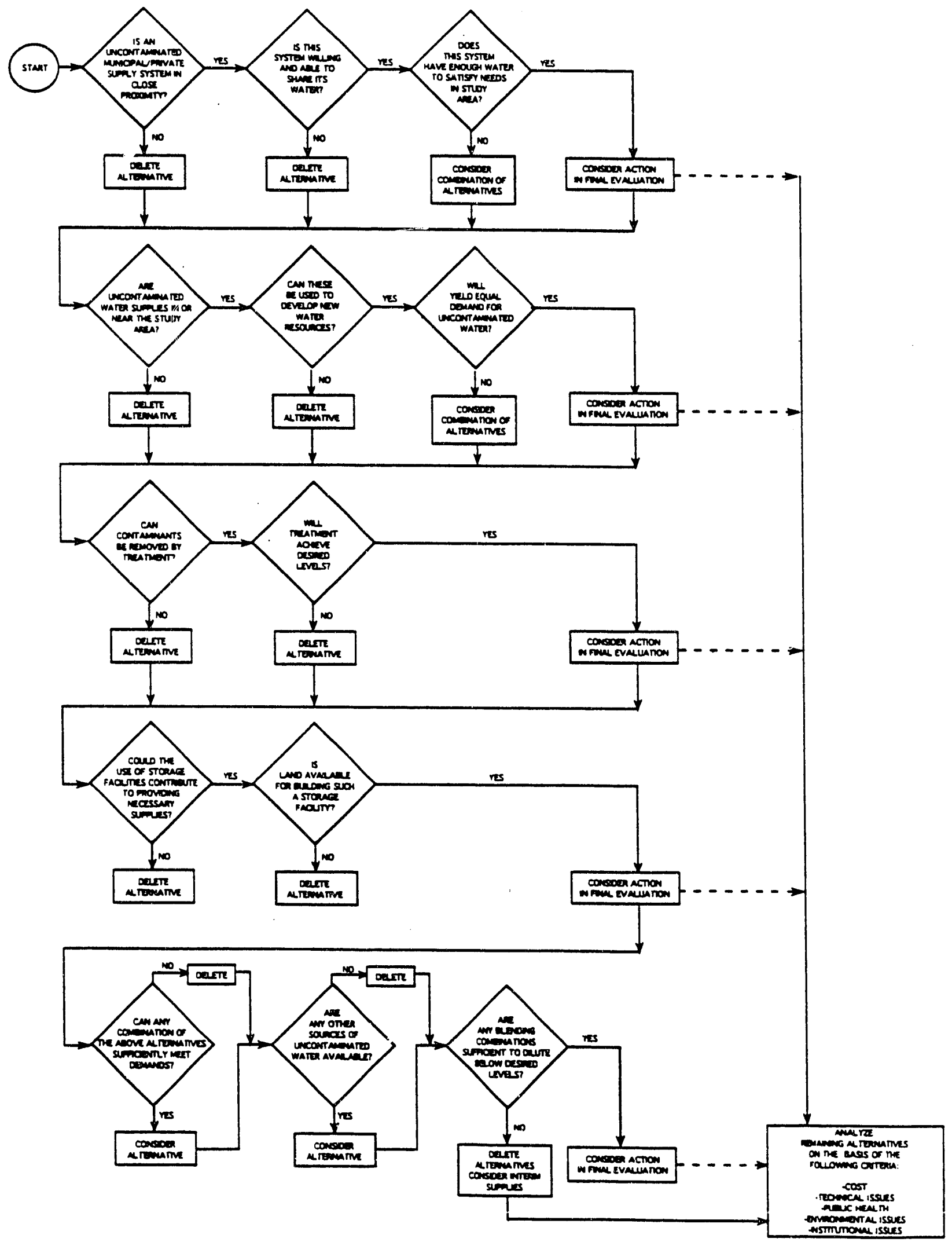

Source: Guidance Document for Providing Alternate Water Supplies, EPA540/G-87/006, OSWER Directive 9355.3-03, February 1988 


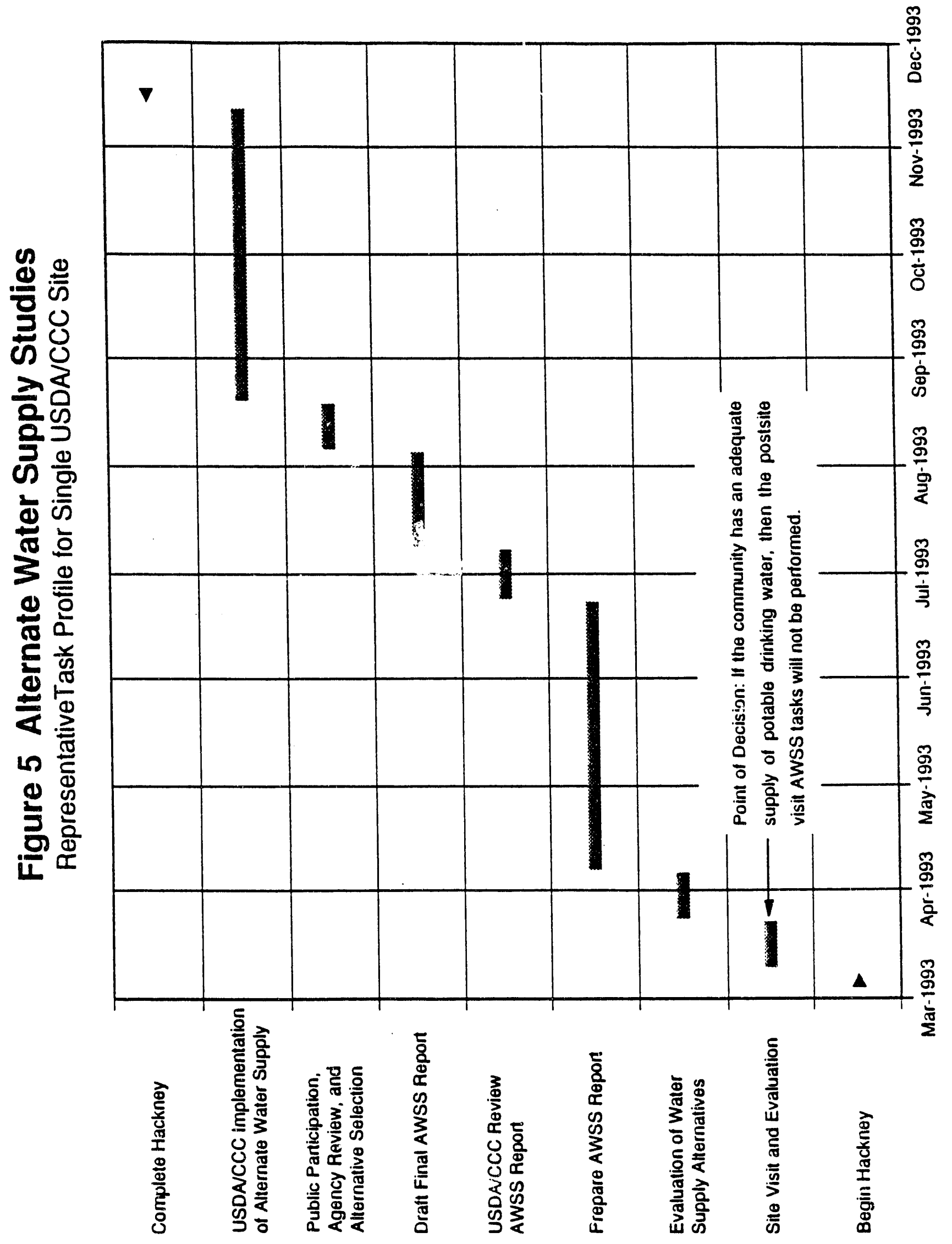




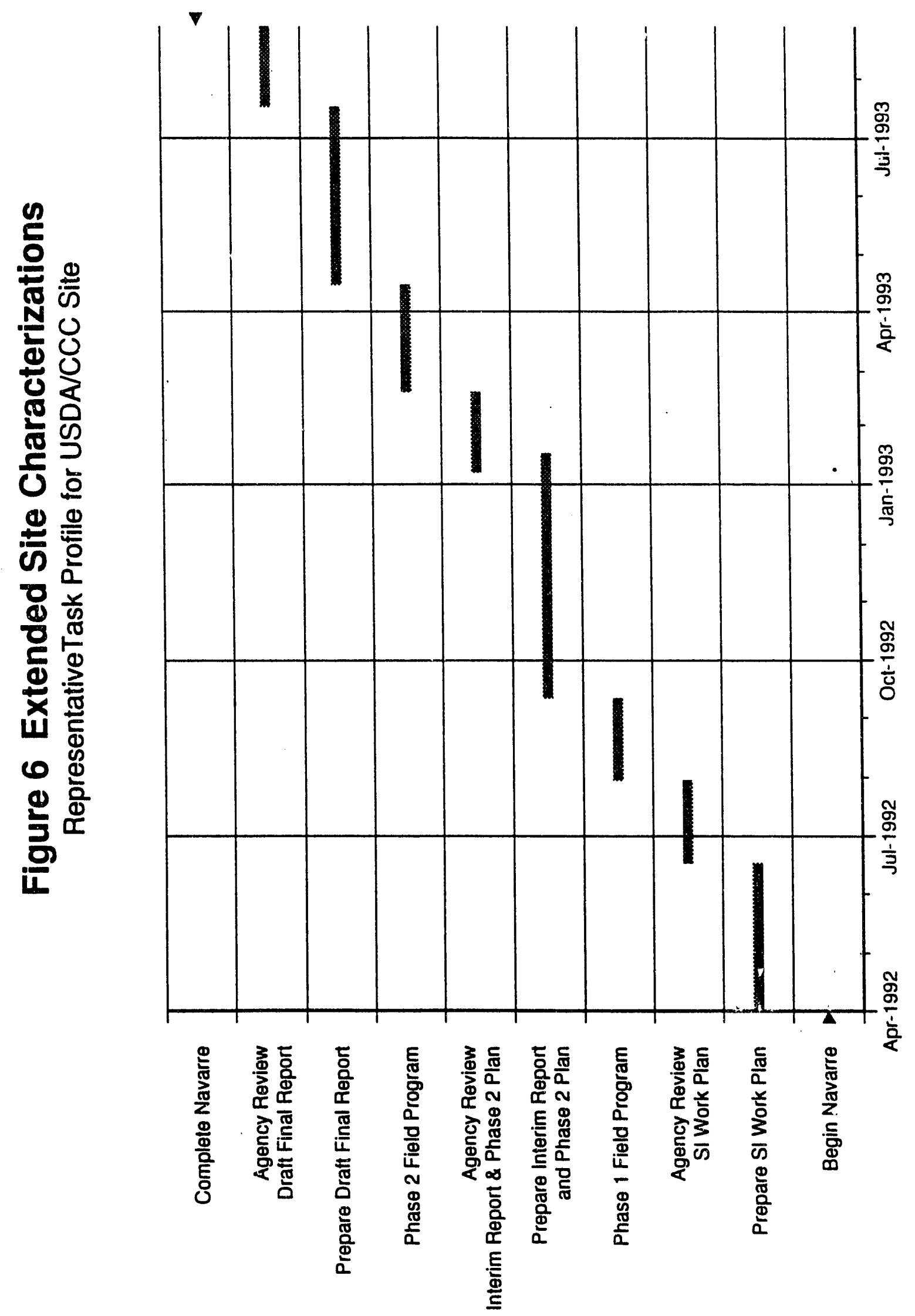



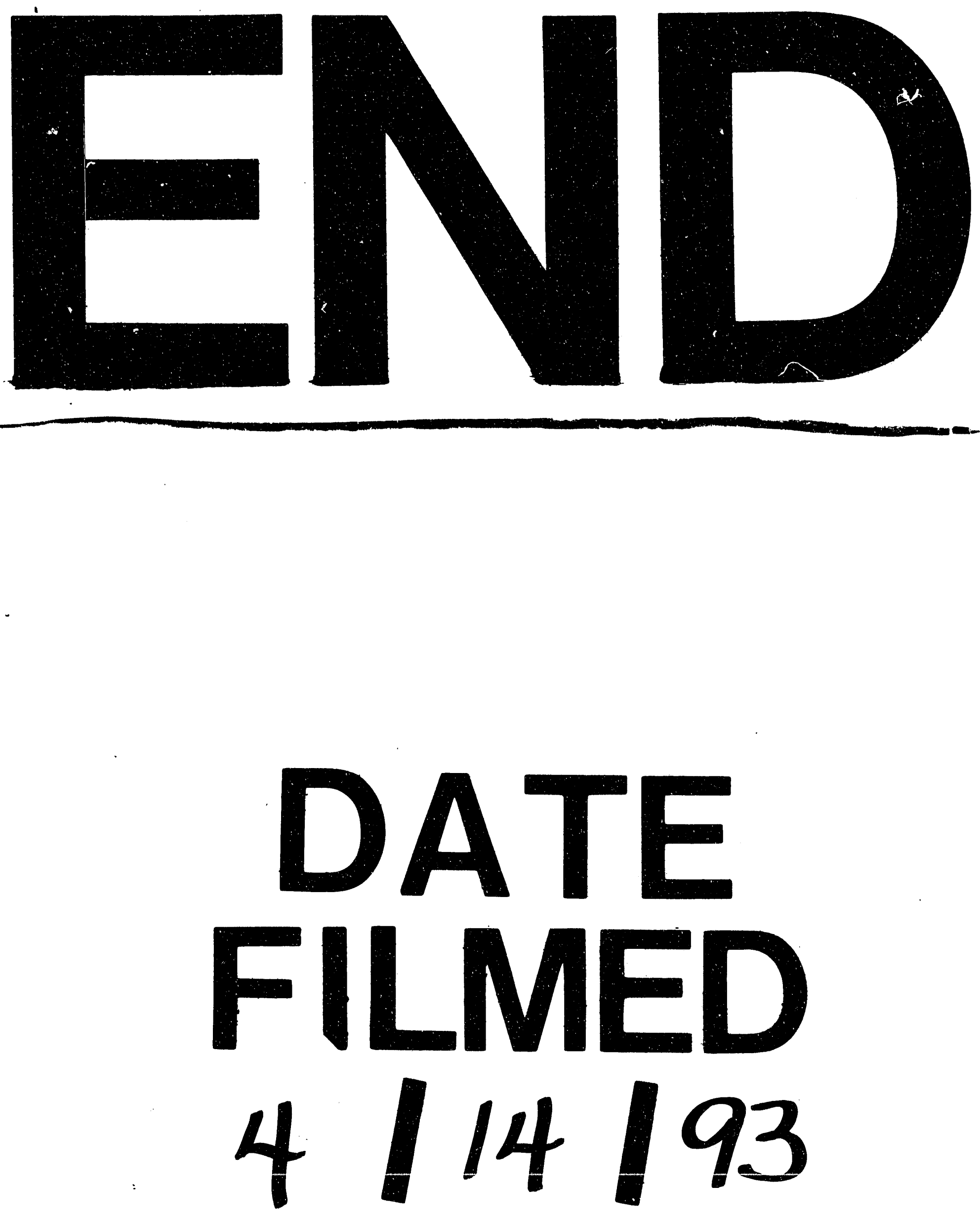
